\title{
QUEERIN MUISTAMISEN TÄRKEYDESTÄ JA VAIKEUDESTA
}

Varpu Alasuutari

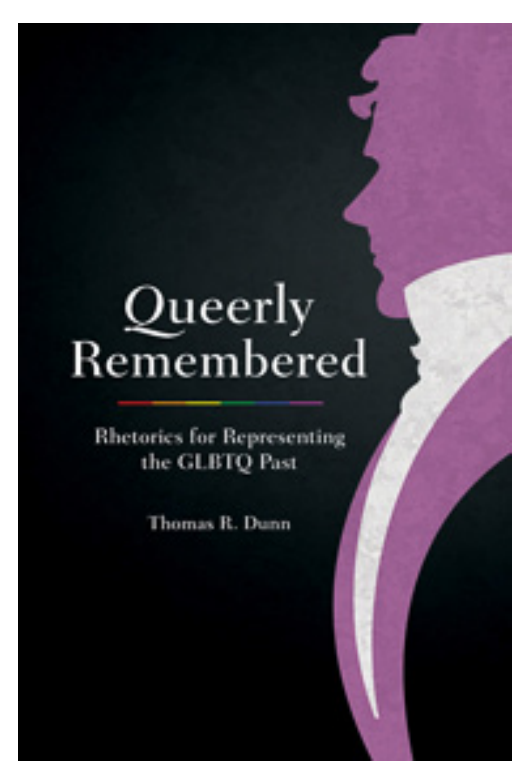

Dunn, Thomas R. Dunn. 2016. Queerly Remembered: Rhetorics for Representing the GLBTQ Past. Columbia: University of South Carolina Press, 232 s.

Thomas R. Dunnin teos Queerly Remembered tarjoaa kiinnostavan näkökulman muistoihin ja muistamiseen LGBTQ-väestön näkökulmasta. Kirjan keskeinen tavoite on selittää queeriä käännettä kohti muistojen, muistamisen ja muistetuksi tulemisen politiikkaa. Aihetta Dunn lähestyy queer-monumentaalisuuden, julkisen muistin ja queerin vastajulkisuuden käsitteiden kautta. Lisäksi hän tekee eron queer-historian ja queermuistamisen välille. Dunnin mukaan niin kutsuttu homo- ja lesbohistoria tuottaa yksittäisiä ja universalisoivia narratiiveja, jotka eivät kuvaa kattavasti LGBTQ-väestön moninaisia kokemuksia. Muistot, jotka Dunn määrittelee aina ajankohtaisiksi, eletyiksi ja ruumiillisiksi kokemuksiksi, tarjoavat hänen mukaansa paremmat edellytykset monipuolisen kuvan tuottamiseksi LGBTQ-ihmisten menneisyydestä.
Dunnin mukaan queer-monumentaalisuuden nousu on ollut nähtävissä 1980-luvulta alkaen. Yksinkertaisimmillaan tämä voidaan ymmärtää muistomerkkien pystyttämiseksi LGBTQ-ihmisten muistoksi. Monumentaalisuuden queerit tulkinnat eivät kuitenkaan ole yksin materiaalisuuteen sidottuja: Dunn määrittelee queer-monumentaalisuuden jatkuvasti kehittyviksi LGBTQ-ihmisten, -yhteisöjen ja -instituutioiden pyrkimyksiksi tuottaa yhteiselle menneisyydelleen painoarvoa, ajattomuutta ja loistoa paitsi omassa piirissään, myös laajemman hetero- ja cisyleisön keskuudessa. Queer-näkökulmien tuomisella osaksi yhteiskuntien julkista muistia on myös retorisia tavoitteita, ja sillä on keskeinen osansa LGBTQ-järjestöjen ja -aktivistien toiminnassa.

Monumentaalisen ilmaisun pysyvyys on paitsi sen etu, myös ongelma. Jäykkänä ilmaisukanavana monumentaalisuuden kautta on vaikea ilmentää muuttuvia ja moninaisia kokemuksia ja identiteettejä. Queer-monumentaalisuutta onkin syytetty homonormatiiviseksi, ja LGBTQ-yhteisöissä on kyseenalaistettu sen kautta tuotettujen muistojen oikeellisuutta ja seuraamuksia. Dunn nimittää näitä vastadiskursseja queeriksi vastajulkisuudeksi. Kritiikistä huolimatta Dunn esittää, että queer-monumentaalisuudelle on tilausta: LGBTQ-väestön menneisyyden näkyväksi tekeminen monumentaalisuuden keinoin tarjoaa mahdollisuuden taistella vallitsevaan heterokulttuuriin ja -historiaan katoamista vastaan.

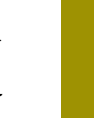




\section{Muistamisen ja unohtamisen politiikka}

Miten määrittelemme, ketkä ovat muistamisen tai unohtamisen arvoisia? Kuinka yksilöt ja yhteisöt muistavat toisiaan? Millaisia muotoja queermonumentaalisuus voi saada, ja mitkä ovat sen rajoitteet? Muun muassa nämä kysymykset Dunn nostaa tutkimuksensa keskiöön ja tarkastelee niitä valikoitujen esimerkkien kautta. Ei ole samantekevää ketkä tulevat muistetuiksi ja esiin nostetuiksi, ja siksi esimerkkien valinta itsessään on poliittinen teko. Lukijana ja queerin kuolemankulttuurin tutkijana olisin kaivannut Dunnilta laajempaa perspektiiviä LGBTQ-yhteisöjen muistelurituaaleihin sekä avoimempaa kuvausta siitä, miten tietyt kohteet valikoituivat kirjan esimerkeiksi.

Dunn omistaa kirjassaan kokonaisen luvun Kanadan Torontoon vuonna 2005 pystytetylle Alexander Woodin patsaalle. Wood oli Torontossa 1800-luvulla elänyt tuomari, jonka uskottiin hyväksikäyttäneen asemaansa lainvalvojana, jotta voisi tarpeettomasti tarkastella miesten genitaaleja rikostutkinnan yhteydessä. Skandaalin myötä Wood sai homoseksuaalin leiman, mutta hänen todellinen seksuaalinen suuntautumisensa jää arvailujen varaan. Sittemmin Woodia on Kanadassa nimitetty"pioneerihomoksi”, ja hänen patsaansa on pystytetty keskeiselle paikalle Toronton homoalueelle. Vaikka patsas herätti vastustusta konservatiivipiireissä, ja homoidentiteetin liittämistä Woodiin kyseenalaistettiin myös queer-yhteisön sisällä, on patsaasta sittemmin tullut varsin suosittu.

Toinen paljon käsittelytilaa saava esimerkki on vuonna 1998 murhatun homomiehen Matthew Shepardin muisto. Shepardin tapaus osoittaa, ettei queer-monumentaalisuus ole aina materiaalista: Shepardille ei ole omistettu Woodin tavoin patsasta, mutta hänen tarinaansa on pidetty vuosien ajan esillä mediassa, mielenosoituksissa ja viharikoslainsäädännön lobbauskampanjoissa. Samalla kun Shepardin muistoa on pidetty yllä, samat toimijat ovat sivuuttaneet monet muut LGBTQ-ihmisiin kohdistuneet murhat. Queeriä vastajulkisuutta edustavat aktivistit ovatkin huomauttaneet, että Shepardista muodostui kuolemansa jälkeen LGBTQihmisten oikeuksia ajavan kampanjan kansikuvapoika siksi, että hän oli konservatiivisen heteroyleisön silmissä kunniallinen ja samaistuttava: valkoinen, keskiluokkainen ja hyväkäytöksinen yliopisto-opiskelija, joka sattui olemaan myös homo.

Näiden esimerkkien ohella Dunn lähestyy queer-monumentaalisuutta myös oppikirjojen näkökulmasta ja havainnollistaa, kuinka oppikirjat ovat tärkeässä osassa muistamisen ja muistetuksi tulemisen politiikassa. Yhdysvalloissa LGBTQ-järjestöt ovat kamppailleet sen puolesta, että oppikirjoihin saataisiin mukaan positiivisia representaatioita LGBTQ-ihmisistä, jotka eri aikoina ovat olleet mukana rakentamassa Yhdysvaltoja ja tekemässä merkittäviä tekoja maansa puolesta. Yhdysvalloissa oppikirjoihin - kuten monumentaalisuuteen yleensä - liittyy vahvasti nationalismi, jonka kanssa myös LGBTQ-järjestöt ovat joutuneet tasapainoilemaan saadakseen oppikirjoihin lisää queer-näkyvyyttä. Dunn huomauttaa osuvasti, että pelkkiin positiivisiin representaatioihin keskittyminen jättää näkymättömäksi LGBTQ-ihmisten syrjintään ja oikeuksien tavoitteluun liittyvän historian. Juuri tämän historian näkyväksi tekeminen olisi kuitenkin ensiarvoisen tärkeä.̈. Kuten Dunn kysyy: voimmeko kuvitella, että historian oppikirjat vaikenisivat muista sorron muodoista, kuten holokaustista, orjuudesta tai naisten alisteisesta asemasta - tai mainitsisivat ne vain alaviitteessä?

Vaikka Dunnin luenta queer-monumentaalisuudesta on kiinnostava keskustelunavaus, ei hän mene sen kriittisessä analyysissä kovinkaan pitkälle. Dunnin esittämä kritiikki on pitkälti referaatinomaista, eikä lukijalle aina tule selväksi mitä Dunn itse kuvailemastaan kritiikistä ajattelee. Vaikka hän muita tutkijoita ja aktivisteja siteeraten tuokin näkyviin esimerkiksi Woodin oletettuun homoidentiteettiin liittyvän anakronistisen historian(1)

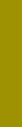

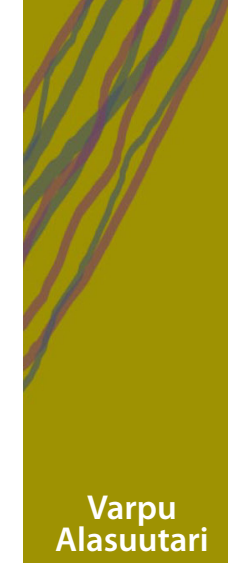


tulkinnan sekä Shepardiin ja viharikoskeskusteluun liittyvän muiden viharikosten uhrien sivuuttamisen ongelmallisuuden, hän ei ota niihin kantaa itse. Samalla hän uusintaa samoja ongelmallisia diskursseja valitsemiensa esimerkkien kautta.

Vaikka Dunn kirjansa yhteenvedossa toteaa pyrkineensä inklusiivisuuteen, toistavat hänen valitsemansa esimerkit muutamia poikkeuksia lukuun ottamatta sitä valkoisten cissukupuolisten homomiesten jalustalle nostamisen kaavaa, jota hän kertoo queerin vastajulkisuuden kritisoineen. Valkoiset, cissukupuoliset miehet, kuten esimerkiksi Alexander Wood ja Yhdysvaltojen entinen presidentti Abraham Lincoln, kelpaavat Dunnin kirjaan esimerkeiksi silloinkin, kun heidän homoseksuaalisuutensa on parhaimmillaankin tulkinnanvaraista. Samalla Dunn vaikenee monista LGBTQ-yhteisön vakiintuneista muistamisen tavoista ja rituaaleista, kuten esimeriksi murhattujen transihmisten muistamiseen keskittyvästä vuosittaisesta ja maailmanlaajuisesta Transgender Day of Remembrance -tapahtumasta. Ottaen huomioon, että yhä edelleen Yhdysvalloissa rodullistetut transnaiset joutuvat muita LGBTQ-ihmisiä useammin viharikosten, pahoinpitelyiden ja murhien kohteiksi, olisi heidän esille nostamisensa ollut Dunnin teoksessa odotettua ja suotavaa. Vaikka Dunn kiittelee queer- ja transaktivisteja yksipuolisen, universalisoivan ja kunniallisuuteen nojaavan queer-monumentaalisuuden kritiikistä, tämän kriittisyyden soisi olevan myös tutkijoiden vastuulla.

\section{Queerit muistamisen rituaalit}

Kiinnostavimmillaan Dunnin teos on kuvatessaan queer-yhteisöissä syntynyttä spontaania muistelukulttuuria, joka haastaa esimerkiksi hautamuistomerkkien normatiivisia luentoja. Dunn kertoo Vietnamin sodassa palvelleen homomiehen Leonard Matlovichin itselleen suunnittelemasta hautakivestä, josta on tullut myös muiden Vietnamin sodan homove- teraanien muistopaikka. Matlovichin hautakivi on houkutellut samalle hautausmaalle myös muita queeriyden eri strategioin näkyväksi tekeviä hautoja. Hautausmaalla, jossa vainajien yksilöllisyys yleensä katoaa normatiivisten hautauskäytäntöjen ja kristillisen kuvaston alle, queeriys voidaan tehdä näkyväksi esimerkiksi normeista poikkeavin värivalinnoin, symbolein ja tekstein. Miltä kuulostaisi vaikkapa vaaleanpunainen hautakivi tai kolmiot ja sateenkaaret enkeleiden ja ristien tilalla? Toinen kiinnostava esimerkki on Patricia Croninin suunnittelema, hautausmaalle sijoitettu patsas Memorial to a Marriage, johon Cronin on kuvannut itsensä alasti vuoteeseen naispuolisonsa kanssa. Croninin teos queeriyttää käsitystä hautamuistomerkeistä lesbosuhteen esiin tuomisen ohella myös toisella tavalla: Cronin ja hänen puolisonsa eivät nimittäin ole vielä kuolleet, eikä hautamuistomerkin yhteydessä ole lainkaan hautaa.

Queerien muistomerkkien ympärille voi myös rakentua spontaania queerkulttuuria, joka saa paikoitellen humoristisia ja camp-henkisiä sävyjä. Esimerkiksi torontolaisessa queer-yhteisössä Woodin patsasta koristellaan erilaisin feminiinisin asustein ja meikein. Lisäksi patsaan luona vierailuun on muodostunut rituaali, jossa katsoja koskettaa patsaan juurella olevaa messinkilaattaa, joka kuvaa Woodin tutkimassa housut nilkoissa seisovaa miestä. Tämän "rubbing the bum" -rituaalin sanotaan tuovan koskettajalle hyvää onnea. Esimerkki osoittaa, että queer-muistomerkkien luovalla queeriyttämisellä LGBTQ-yhteisö voi ottaa muistomerkit omakseen mielikuvituksellisilla tavoilla.

\section{Queer-monumentaalisuuden tulevaisuus}

Dunnin mukaan queer-monumentaalisuus elää kulta-aikaansa ja tulee todennäköisesti lisääntymään tulevaisuudessa. Näkyvien, materiaalisten muistomerkkien rinnalla kulkevat yhä myös puolijulkiset, epämääräiset ja osin ohimenevätkin queerit muistelurituaalit, joilla on ollut merkittävä 
paikkansa queerin muistelun menneisyydessä, jolloin julkisista muistomerkeistä voitiin tuskin edes haaveilla. Myös nämä muistamisen tavat tulevat Dunnin mukaan säilymään, sillä ne ovat erottamaton osa queeriä elämää.

Dunnin kirja saa pohtimaan queer-monumentaalisuuden nykytilaa ja mahdollisuuksia Suomen kontekstissa, jossa aiheen julkinen keskustelu on keskittynyt lähinnä homoeroottisesta taiteestaan tunnettuun Touko Laaksoseen eli Tom of Finlandiin. Millaisia spontaanin queerejä rituaaleja mahtaakaan syntyä Turkuun tulevalle Tom of Finlandin aukiolle? Aukion ohella Suomeen on kaavailtu Tom of Finlandin kunniaksi myös patsasta, mutta suunnitelma on tyssännyt Helsingin kaupunginvaltuuston vastustukseen.

Queereistä muistomerkeistä käytävässä keskustelussa oleellista tuntuu olevan se, kuinka näkyvä tai näkymätön muistomerkki saa olla. Helsingissä patsasta ehdotettiin pystytettäväksi keskeiselle paikalle keskustakirjaston edustalle, mutta sijainti kaupungin paraatipaikalla herätti pahennusta konservatiivisten kunnanvaltuutettujen keskuudessa. Osa kannatti patsasta, mikäli se piilotettaisiin esimerkiksi Karhupuistoon tai "jonnekin huomaamattomaan paikkaan Kallioon". Mielenkiintoisesti Turussa Tom of Finlandin aukion sijainniksi on valittu keskeinen paikka kulttuurikeskus Logomon edustalla kaupungin keskustassa, vaikka sijainnilla ei ole mitään yhteyttä Touko Laaksoseen henkilönä. Perusteluna aukion sijainnille käytettiin tosin sen hyödyntämismahdollisuuksia turistikohteena, jolloin painoarvoa tuntuu olevan enemmän LGBTQ-matkailijoiden pinkillä rahalla kuin queerillä muistamisella sinänsä. Tämä resonoi Dunnin tekemien havaintojen kanssa, joiden mukaan queer-monumentaalisuuden motiivit voivat joskus olla lähtöisin aivan jostain muualta kuin queer-yhteisöstä itsestään.

Tom of Finlandin tapausesimerkissä kiinnostavaa on myös se, että Tomin taide on ronskin avoimessa seksuaalisuudessaan kaukana Dunnin kuvaa- masta kunniallisuuden vaatimuksesta, jota queer-muistomerkeiltä yleensä edellytetään. Toisaalta Tom of Finlandin nostaminen queerin muistamisen keskiöön toisintaa jälleen sitä kaavaa, jossa huomion ja muistamisen kohteeksi kelpaavat lähinnä valkoiset cissukupuoliset homomiehet. Onkin syytä kysyä, riittääkö meille se, että muistamme Tom of Finlandin, Alexander Woodin tai Matthew Shepardin. Kuinka voisimme muistella queeriyttä ja queerejä laajemmin? Millainen olisi muistomerkki, jossa huomio jakautuisi laajemmin moninaisen LGBTQ-väestön kesken? Nämä ovat kysymyksiä, jotka Dunnin kirjassa jäävät vielä vaille vastauksia. 